\title{
PENGARUH KOMPETENSI APARATUR SIPIL NEGARA DAN KUALITAS SISTEM AKUNTANSI INSTANSI TERHADAP KUALITAS PENYAJIAN DANA DEKONSENTRASI DALAM LAPORAN KEUANGAN DI PROVINSI SULAWESI UTARA
}

\author{
Arthur Johanes Pontoh ${ }^{1}$, Grace B. Nangoi ${ }^{2}$, Robert Lambey ${ }^{3}$ \\ 1,2,3 Fakultas Ekonomi dan Bisnis, Jurusan Akuntansi, Universitas Sam Ratulangi, Jl. Kampus Bahu, Manado, \\ 95115, Indonesia \\ E-mail : arthurjpontoh@yahoo.com
}

\begin{abstract}
The purpose of this study aims to know the influence of State Civil Apparatus competence and system quality of agency accounting on the quality of presentation of deconcentration funds in the financial statements in North Sulawesi. Data collection by questionnaire from 42 respondents in Regional Apparatus Work Unit in North Sulawesi which manages deconcentration funds. Data were analyzed using Multiple Linear Regression analysis method with the help of SPSS 22. The results of this study indicate that the State Civil Apparatus competence partially has an effect on the quality of presentation of deconcentration funds in the financial statements with test results $\left(t_{\text {hitung }} 2,573>t_{\text {table }} 2,02269\right.$ and the significance value is 0,014<0,05). While system quality of agency accounting does not affect the quality of presentation of deconcentration funds in the financial statements with test results ( $t_{\text {hitung }} 0,861<t_{\text {table }} 2,02269$ and the significance value is $0,395>0,05$ )

Keywords: State Civil Apparatus Competence, System Quality of Agency Accounting, Quality of Presentation of Deconcentration Funds in the Financial Statements.
\end{abstract}

\section{PENDAHULUAN}

Pemerintah Indonesia dalam melaksanakan urusan yang menjadi kewenangannya di daerah, berdasarkan azas otonomi dan tugas pembantuan dengan prinsip otonomi seluasluasnya dalam sistem dan prinsip Negara Kesatuan Republik Indonesia sebagaimana yang dimaksud dalam Undang-Undang Dasar Negara Republik Indonesia Tahun 1945, melimpahkan sebagaian kewenangannya kepada Gubernur selaku wakil pemerintah pusat di daerah dan dilaksanakan berdasarkan azas dekonsentrasi dan tugas pembantuan, hal ini diatur dalam Peraturan Pemerintah Nomor 7 Tahun 2008 tentang Dekonsentrasi dan Tugas Pembantuan, dimana penyelenggaraan dekonsentrasi dilakukan melalui pelimpahan sebagian urusan pemerintah yang menjadi kewenangan kementerian dan lembaga. Dalam menunjang pelaksanaan dekonsentrasi di Pemerintah Provinsi Sulawesi Utara, Pemerintah Pusat lewat Kementerian mengalokasikan dana dekonsentrasi di Pemerintah Provinsi Sulawesi Utara adalah sebesar Rp. 165,213,345,000 yang tersalurkan di 20 perangkat daerah Provinsi Sulawesi Utara sebagai berikut : 


\section{Tabel 1.1}

Perangkat Daerah Provinsi Sulawesi Utara yang mengelola dana dekonsentrasi

\begin{tabular}{|c|c|c|}
\hline No. & Perangkat Daerah & Pagu \\
\hline 1. & Dinas Lingkungan Hidup Daerah Prov. Sulut & $550,000,000$ \\
\hline 2. & Dinas Perkebunan Daerah Prov. Sulut & $687,460,000$ \\
\hline 3. & $\begin{array}{l}\text { Dinas Penanaman Modal dan Pelayanan Terpadu Satu } \\
\text { Pintu Daerah Prov. Sulut }\end{array}$ & $711,498,000$ \\
\hline 4. & Dinas Kehutanan Daerah Prov. Sulut & $939,400,000$ \\
\hline 5. & Bappeda Prov. Sulut & $1,079,491,000$ \\
\hline 6. & Sekretariat Daerah Provinsi Sulawesi Utara & $1,159,769,000$ \\
\hline 7. & Dinas Kebudayaan dan Pariwisata Daerah Prov. Sulut & $1,482,000,000$ \\
\hline 8. & Dinas Perpustakaan dan Kearsipan Daerah Prov. Sulut & $1,540,082,000$ \\
\hline 9. & Dinas Koperasi dan UMKM Daerah Prov. Sulut & $2,201,971,000$ \\
\hline 10. & $\begin{array}{l}\text { Dinas Pemberdayaan Perempuan dan Perlindungan Anak } \\
\text { Daerah Prov. Sulut }\end{array}$ & $2,360,000,000$ \\
\hline 11. & Dinas Kelautan dan Perikanan Daerah Prov. Sulut & $3,241,485,000$ \\
\hline 12. & Dinas Pangan Daerah Prov. Sulut & $3,287,500,000$ \\
\hline 13. & $\begin{array}{l}\text { Dinas Tenaga Kerja dan Transmigrasi Daerah Prov. } \\
\text { Sulut }\end{array}$ & $3,812,394,000$ \\
\hline 14. & Dinas Kepemudaan dan Olahraga Daerah Prov. Sulut & $4,273,634,000$ \\
\hline 15. & Dinas Perindustrian dan Perdagangan Daerah Prov. Sulut & $5,507,308,000$ \\
\hline 16. & Dinas Pendidikan Daerah Prov. Sulut & $10,700,675,000$ \\
\hline 17. & Dinas Sosial Daerah Prov. Sulut & $14,157,002,000$ \\
\hline 18. & Dinas Pertanian dan Peternakan Daerah Prov. Sulut & $24,234,401,000$ \\
\hline 19. & Dinas Kesehatan Daerah Prov. Sulut & $35,868,979,000$ \\
\hline 20. & $\begin{array}{l}\text { Dinas Pemberdayaan Masyarakat dan Pemerintahan } \\
\text { Daerah Prov. Sulut }\end{array}$ & $47,295,220,000$ \\
\hline \multicolumn{2}{|c|}{ TOTAL } & $165,213,345,00$ \\
\hline
\end{tabular}

Sumber : Bappeda Provinsi Sulawesi Utara, 2017

Berdasarkan Tabel 1.1 diatas dengan alokasi dana dekonsentrasi di Pemerintah Provinsi Sulawesi Utara yang mencapai Rp.165,213,345,000 atau sekitar 1,87 persen dari total dana APBN di Pemerintah Provinsi Sulawesi Utara maka diperlukan kompetensi Aparatur Sipil Negara (ASN) dalam mengelola dana dekonsentrasi serta diperlukan juga kualitas sistem akuntansi instansi dalam pengelolaan dana dekonsentrasi sehingga dapat menghasilkan kualitas penyajian dana dekonsentrasi dalam laporan keuangan di Provinsi Sulawesi Utara.

Laporan keuangan Satuan Kerja Perangkat Daerah (SKPD) adalah bentuk pertanggungjawaban atas pelaksanaan Dana Dekonsentrasi berupa Laporan Realisasi Anggaran (LRA), Laporan Operasional (LO), Laporan Perubahan Ekuitas (LPE), Neraca dan Catatan atas Laporan Keuangan (CaLK). Keandalan laporan keuangan yang dihasilkan oleh satuan kerja perangkat daerah yang mengelola dana dekonsentrasi dengan proses rekonsiliasi. Rekonsiliasi adalah proses pencocokan data transaksi keuangan yang diproses dengan sistem/sub sistem yang berbeda berdasarkan dokumen sumber yang sama. Rekonsiliasi merupakan salah satu kunci utama dalam penyusunan laporan keuangan yang kredibel.

Sejalan dengan perkembangan kompetensi Aparatur Sipil Negara (ASN) di bidang akuntansi maka dibutuhan ASN yang mempunyai produktivitas tinggi untuk semua instansi pemerintah dalam mencapai keberhasilan pelaksanaan pekerjaan yang diinginkan. Sehubungan dengan hal tersebut, diperlukan kompetensi Aparatur Sipil Negara (ASN) yang memiliki pengetahuan mengenai akuntansi pemerintahan, keterampilan dalam menggunakan 
aplikasi saiba dan aplikasi sas serta sikap yang berkomitmen dengan pekerjaan dan selalu mengedepankan kode etik Aparatur Sipil Negara. Kompetensi adalah karakteristik seseorang yang berkaitan dengan kinerja efektif dan atau unggul dalam situasi pekerjaan tertentu, kompetensi dikatakan sebagai karakteristik dasar (underlying characteristic) karena karakteristik individu merupakan bagian yang mendalam dan melekat pada kepribadian seseorang yang dapat dipergunakan untuk memprediksi berbagai situasi pekerjaan tertentu. Kemudian dikatakan berkaitan antara perilaku dan kinerja karena kompetensi ASN dapat menghasilkan kesuksesan dalam suatu pekerjaan.

Selain kompetensi ASN, hal yang juga berhubungan dengan kualitas penyajian dana dekonsentrasi dalam laporan keuangan adalah Kualitas Sistem Akuntansi Instansi (SAI). Sistem Akuntansi Instansi (SAI) adalah serangkaian prosedur manual maupun yang terkomputerisasi mulai dari pengumpulan data, pencatatan, pengikhtisaran sampai dengan pelaporan posisi keuangan dan operasi keuangan pada Kementerian Negara/Lembaga. Pentingnya kualitas SAI dalam membuat laporan keuangan instansi, diharapkan setiap instansi pemerintah dan tidak terkecuali bagi Satker yang berada di Pemerintahan Provinsi Sulawesi Utara untuk menyelenggarakan sistem akuntansi instansi sebagai sistem akuntansi guna menyampaikan pertanggungjawaban laporan keuangan instansi kepada Kantor Pelayanan Perbendaharaan Negara (KPPN). Hal ini sesuai dengan Peraturan Pemerintah Nomor 08 Tahun 2006 Tentang Pelaporan Keuangan dan Kinerja Instansi Pemerintah.

Sistem Akuntansi Instansi (SAI) merupakan langkah pemerintah dalam membangun sistem aplikasi pengelolaan dana yang ada di instansi pemerintah, guna mendukung tercapainya pengelolaan dana yang efektif dan efisien. Pengembangan dan pengaplikasian akuntansi instansi penting sebagai alat untuk melakukan transparansi dalam mewujudkan laporan keuangan yang akuntabel. Sistem Akuntansi Instansi dirancang juga untuk memudahkan instansi dalam penyajian dana dekonsentrasi dalam laporan keuangan. Penyajian dana dekonsentrasi dalam laporan keuangan masih terdapat beberapa keterlambatan dalam menyampaikan pertanggungjawaban laporan keuangan oleh satker yang berada dilingkup Pemerintah Provinsi Sulawesi Utara ke KPPN Provinsi Sulawesi Utara maupun ke Pemerintah Pusat, karena kemungkinan hal ini disebabkan oleh kompetensi Aparatur Sipil Negara yang kurang efektif dan efisien dalam penggunaan sistem akuntansi instansi.

Berdasarkan uraian latar belakang permasalahan tersebut diatas, maka penelitian ini dimaksudkan untuk menjawab rumusan masalah sebagai berikut :

1. Apakah Kompetensi Aparatur Sipil Negara berpengaruh terhadap kualitas penyajian dana dekonsentrasi dalam laporan keuangan di Provinsi Sulawasi Utara?

2. Apakah Kualitas Sistem Akuntansi Instansi berpengaruh terhadap kualitas penyajian dana dekonsentrasi dalam laporan keuangan di Provinsi Sulawasi Utara?

Agar penelitian ini dapat terarah dan tidak menyimpang dari permasalahan yang akan diteliti, maka perlu adanya batasan masalah. Peneliti ingin membuktikan pengaruh kompetensi ASN dan kualitas sistem akuntansi instansi terhadap kualitas penyajian dana dekonsentrasi dalam laporan keuangan. Kompetensi ASN yang dimaksud dalam penelitian ini adalah kemampuan aparatur sipil negara dalam menghasilkan penyajian dana dekonsentrasi dalam laporan keuangan yang berkualitas. Kualitas sistem akuntansi instansi yang dimaksud yaitu manfaat dari adanya sebuah sistem yang memadai dalam proses penyajian dana dekonsentrasi dalam laporan keuangan yang berkualitas. Dan untuk objek penelitian, peneliti mengambil lima Satuan Kerja Perangkat Daerah di Provinsi Sulawesi Utara yang mengelola dana dekonsentasi. 


\section{TINJAUAN PUSTAKA}

\subsection{Teori Kegunaan Keputusan}

Penelitian ini menggunakan teori kegunaan keputusan (decision-usefulness theory) informasi akuntansi. Orang pertama yang menggunakan paradigma kegunaan keputusan (decision-usefulness) adalah Chambers dikutip dari Agus Tenaya (2005). Ia mengatakan sebagai berikut: oleh karenanya, akibat yang wajar dari asumsi manajemen rasional adalah bahwa seharusnya ada sistem yang menyajikan suatu informasi; seperti sistem yang diperlukan baik untuk dasar pembuatan keputusan atau dasar untuk memperoleh kembali konsekuensi keputusan. Sistem yang menyajikan informasi secara formal akan menyesuaikan dengan dua dalil umum. Pertama adalah kondisi dari setiap wacana ilmiah, sistem seharusnya secara logika konsisten; tidak ada aturan atau proses yang dapat bertentangan dengan setiap aturan atau proses lainnya. Kedua muncul dari pemakai laporan akuntansi sebagai dasar pembuatan keputusan dari konsekuensi praktik, informasi yang dihasilkan oleh setiap sistem seharusnya relevan dengan berbagai bentuk pembuatan keputusan yang diharapkan dapat digunakan.

Statement of Financial Accounting Concepts No. 8 tentang Conceptual Frameworks for Financial Reporting menyatakan bahwa informasi keuangan harus memiliki karakteristik kualitatif yang fundamental untuk menjadi berguna. Teori kegunaan keputusan informasi sangat relevan, karena Standar Akuntansi Pemerintah di Indonesia mengadopsi karakteristik kualitatif dari SFAC No. 8, hanya saja Standar Akuntansi Pemerintahab (SAP) menekankan pada empat prasyarat normatif yakni; relevan, andal, dapat dibandingkan, dan dapat dipahami.

\subsection{Hubungan Kompetensi ASN dan Kualitas Penyajian Dana Dekonsentrasi dalam Laporan Keuangan}

Seseorang yang kompeten adalah yang memiliki kemampuan, pengetahuan dan keahlian untuk melakukan sesuatu secara efisien dan efektif. Undang-Undang Nomor 13 Tahun 2003 tentang Ketenagakerjaan pasal 1 ayat 15 menyatakan bahwa Kompetensi adalah kemampuan kerja setiap individu yang mencakup aspek pengetahuan, keterampilan dan sikap kerja yang sesuai dengan standar yang ditetapkan.

Kompetensi menjadi faktor kunci yang dapat digunakan untuk mencapai keunggulan dalam bersaing (competitive advantage). Kompetensi pegawai negeri sipil adalah kemampuan dan karakteristik yang dimiliki oleh pegawai negeri sipil berupa pengetahuan, keterampilan dan sikap perilaku yang diperlukan dalam pelaksanaan tugas jabatannya (PP No. 101 Tahun 2000 penjelasan pasal 3).

Hutapea dan Thoha (2008:28) mengungkapkan bahwa ada tiga komponen utama pembentukan kompentensi, yaitu:

1. Pengetahuan (knowledge)

2. Keterampilan (skill)

3. Sikap (attitude)

\section{H1 : Kompetensi ASN berpengaruh terhadap Kualitas Penyajian Dana Dekonsentrasi dalam Laporan Keuangan}

\subsection{Hubungan Kualitas Sistem Akuntansi Instansi dan Kualitas Penyajian Dana} Dekonsentrasi dalam Laporan Keuangan

Berdasarkan Peraturan Menteri Keuangan Nomor 213/PMK.05/2013 tentang Sistem Akuntansi dan Pelaporan Keuangan Pemerintah Pusat bahwa "Sistem Akuntansi Instansi merupakan serangkaian prosedur manual maupun terkomputerisasi mulai dari pengumpulan data, pencatatan, pengikhtisaran sampai dengan pelaporan posisi keuangan dan operasi keuangan pada Kementerian Negara/Lembaga. Sistem Akuntansi Instansi merupakan bagian dari Sistem Akuntansi Pemerintah Pusat (SAPP) yang bertujuan untuk menghasilkan laporan 
keuangan pemerintah pusat, dan setiap Kementerian Negara/Lembaga wajib menyelenggarakan Sistem Akuntansi Instansi untuk menghasilkan laporan keuangan.

Sistem akuntansi adalah organisasi formulir, catatan dan laporan yang dikoordinasi sedemikian rupa untuk menyediakan informasi keuangan yang dibutuhkan oleh manajemen guna memudahkan pengelolaan perusahaan (Mulyadi, 2008:3). Dengan menganut definisi bahwa kualitas sistem berarti kualitas dari kombinasi hardware dan software dalam sistem informasi (DeLone dan McLean, 1992). Kualitas sistem dalam sistem akuntansi instansi ini menyangkut keterkaitan fitur dalam sistem termasuk performa sistem dan user interface. Selanjutnya menurut Nelson, et. al (2005) dan dalam penelitian Irfan Bachtiar (2016) kualitas sistem akuntansi dapat diukur dengan karakteristik : "Aksesibilitas (accessibility), Kehandalan (reliability), Waktu Respon (response time), Fleksibilitas (flexibility), dan Integrasi (integration)". Hal yang sama juga dikatakan oleh Marcus Heidmann (2008:87-91) dalam bukunya The Role of Management Accounting Systems in Strategic Sensemaking mengatakan bahwa ada lima karakteristik yang dapat mengukur kualitas sistem akuntansi yaitu : Integration, Flexibility, Accessibility, Formalization and Media Richness. Selanjutnya menurut American Institute of Chartered Public Accountants (AICPA 2004) dikutip dari M. Sidik (2014) kualitas suatu sistem akuntansi yaitu : ketersediaan, keamanan, dapat dipelihara dan integrasi.

H2 : Kualitas Sistem Akuntansi Instansi berpengaruh terhadap Kualitas Penyajian Dana Dekonsentrasi dalam Laporan Keuangan

\subsection{Kualitas Penyajian Dana Dekonsentrasi dalam Laporan Keuangan}

Berdasarkan Peraturan Pemerintah Nomor 7 Tahun 2008 tentang Dana Dekonsentrasi dan Tugas Pembantuan, Dekonsentrasi adalah pelimpahan wewenang dari Pemerintah kepada Gubernur sebagai wakil pemerintah dan/atau kepada Instansi Vertikal di wilayah tertentu. Dana Dekonsentrasi adalah dana yang berasal dari APBN yang dilaksanakan oleh Gubernur selaku wakil pemerintah yang mencakup semua penerimaan dan pengeluaran dalam rangka pelaksanaan dekonsentrasi, tidak termasuk dana yang dialokasikan untuk instansi vertical pusat di daerah. Pendanaan dalam rangka dekonsentrasi dialokasikan untuk kegiatan yang bersifat non fisik yang tidak menambah aset. Pendanaan dalam rangka dekonsentrasi ditujukan untuk kegiatan fasilitasi, pelatihan, penyuluhan, supervisi dan survey. Namun sebagian kecil Dana Dekonsentrasi dapat digunakan untuk membeli barang milik Negara yang dipergunakan sebagai penunjang untuk mendukung pelaksanaan kegiatan dekonsentrasi, dan SKPD wajib untuk melakukan penatausahaan Barang Milik Negara tersebut.

SKPD selaku UAKPA Dekonsentrasi wajib menyampaikan LRA dan Neraca beserta ADK setiap bulan ke KPPN untuk melakukan rekonsiliasi, apabila hasil rekonsiliasi UAKPA dengan KPPN menyatakan kesesuaian maka kesesuaian tersebut akan dicantumkan pada sebuah Berita Acara Rekonsiliasi (BAR). UAKPA Dekonsentrasi juga wajib menyampaikan Laporan Realisasi Anggaran dan Neraca berserta ADK setiap bulan ke UAPPA-W Dekonsentrasi dan UAPPA-E1 yang mengalokasikan Dana Dekonsentrasi. Laporan keuangan pemerintah pusat yang disusun di tingkat Unit Akuntansi Kuasa Pengguna Anggaran / Satuan Kerja Perangkat Daerah, meliputi ; Laporan Realisasi Anggaran, Laporan Operasional, Laporan Perubahan Ekuitas, Neraca dan Catatan Atas Laporan Keuangan.

Karakteristik Laporan keuangan Pemerintah Indonesia diatur dengan Peraturan Pemerintah No. 71 Tahun 2010 tentang Standar Akuntansi Pemerintahan yang menyatakan bahwa karakteristik kualitatif laporan keuangan adalah ukuran-ukuran normatif yang perlu diwujudkan dalam informasi akuntansi sehingga dapat memenuhi tujuannya. Karakteritstik kualitatif tersebut dapat dijelaskan sebagai berikut :

1. Relevan

2. Andal.

3. Dapat Dibandingkan. 


\section{Dapat Dipahami.}

\subsection{Kerangka Pemikiran}

Dalam penelitian ini, dengan menggunakan teori sikap dan perilaku, kerangka pemikiran menggambarkan hubungan antara variabel independen dan variabel dependen. Variabel independen penelitian meliputi Kompetensi ASN dan Kualitas Sistem Akuntansi Instansi. Sedangkan variabel dependen adalah Kualitas Penyajian Dana Dekonsentrasi dalam Laporan Keuangan. Kerangka pemikiran dapat ditunjukkan pada Gambar 2.1 berikut :

\section{Gambar 2.1 Kerangka Pemikiran}

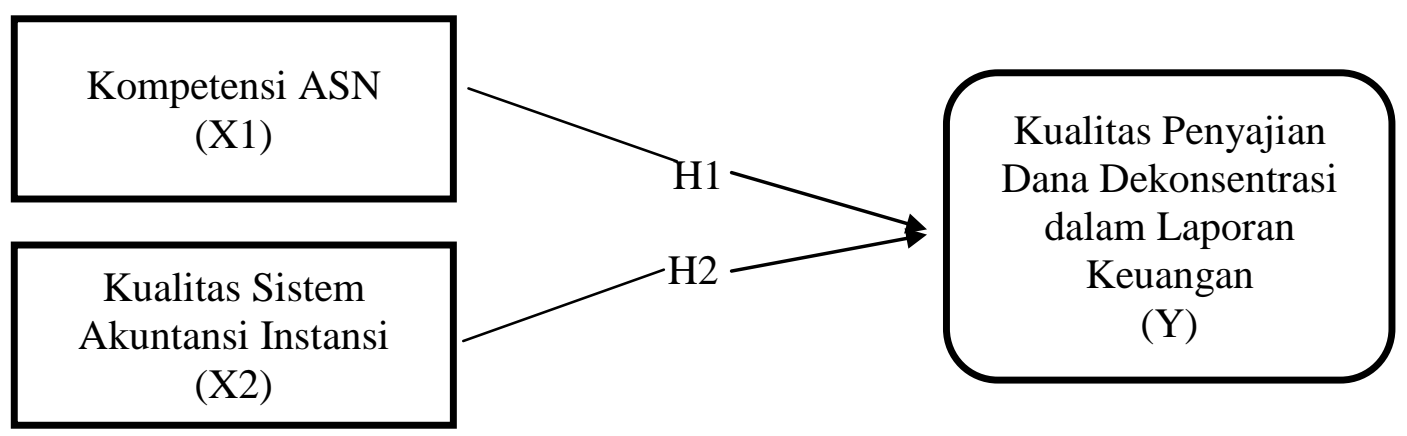

\section{METODE PENELITIAN}

\subsection{Jenis dan sumber data}

Data yang dibutuhkan dalam penelitian ini adalah data primer. Data primer adalah data yang hanya dapat diperoleh dari sumber asli atau pertama. Data primer harus secara langsung kita ambil dari sumber aslinya, melalui narasumber yang tepat dan yang kita jadikan responden dalam penelitian. Sedangkan sumber data primer dalam penelitian ini diperoleh dari jawaban atas kuesioner yang dibagikan kepada responden.

\subsection{Sampel dan teknik pengambilan sampel}

Teknik pengambilan sampel dalam penelitian ini berupa purposive sampling, dimana hanya seseorang atau sesuatu hal yang diambil sebagai sampel. Hal ini dikarenakan bahwa seseorang atau sesuatu tersebut memiliki informasi yang diperlukan bagi penelitian.

Rumus yang digunakan untuk dalam penentuan sampel yaitu menggunakan rumus Slovin adalah :

$$
n=\frac{N}{1+\left(N \cdot a^{2}\right)}
$$

Keterangan :

$\mathrm{n} \quad=$ Jumlah Sampel

$\mathrm{N}=$ Jumlah Populasi

$\mathrm{a}^{2}=$ Persen kelonggaran ketidaktelitian karena kesalahan pengambilan keputusan sampel dalam penelitian, presisi yang digunakan dalam penelitian adalah $1 \%$, $5 \%$ atau $10 \%$

Presisi yang digunakan dalam penelitian ini adalah 5\%, maka perhitungannya adalah sebagai berikut :

$$
n=\frac{42}{1+\left(42 \cdot 0,05^{2}\right)}=38
$$


Berdasarkan perhitungan pengambilan sampel di atas maka yang menjadi sampel dalam penelitian sebanyak 38 responden. Namun karena kepentingan penelitian maka sampel yang diambil semua populasi yaitu sebanyak 42 responden.

\subsection{Metode analisis}

Data penelitian akan dianalisis dengan menggunakan analisis statistik yang meliputi analisis dektriptif, uji kualitas data, uji asumsi klasik, dan uji hipotesis. Berikut ini adalah uraian dari setiap analisis statistik tersebut.

1. Analisis Deskriptif, pada umumnya biasa digunakan untuk memberikan informasi mengenai karakteristik variabel penelitian yang utama dan data demografi responden (jika ada). Tabulasi menyajikan ringkasan, pengaturan atau penyusunan data dalam bentuk tabel numerik dan grafik. Analisis deskriptif dalam penelitian ini disajikan untuk memberikan gambaran tentang karakteristik variabel penelitian, antara lain: nilai minimum, maximum, mean, dan standar deviasi.

2. Uji Kualitas Data dan Uji Reliabilitas

Pengujian instrumen penelitian baik dari segi validitas maupun realibilitas yang dilakukan terhadap 42 responden. Hasil menunjukkan bahwa semua instrumen penelitian yang digunakan valid, dimana nilai signifikansi berada $<0,05$. Selain itu, hasil menunjukkan bahwa semua instrumen penelitian realibel, dimana nilai Cronbach Alpha lebih besar dari 0,6 .

3. Uji Asumsi Klasik:

a. Uji Normalitas.

Untuk menguji Model regresi memiliki distribusi normal atau tidak dapat dilihat menggunakan probability plot menunjukkan bahwa data menyebar di sekitar garis diagonal sehingga data dikatakan berdistribusi normal sehingga memenuhi asumsi normalitas yang dibutuhkan dalam persamaan regresi. Pada penelitian ini uji normalitas menggunakan uji Kolmogorov-Smirnov dengan nilai signifikan sebesar 0,200. Dengan demikian model regresi telah memenuhi asumsi normalitas.

b. Uji Multikolinearitas.

Berdasarkan hasil pengujian menunjukkan bahwa nilai tolerance untuk variabel kompetensi aparatur sipil negara yaitu sebesar 0,631 dan nilai VIF sebesar 1,585; nilai tolerance untuk variabel kualitas sistem akuntansi instansi yaitu sebesar 0,631 dan nilai VIF sebesar 1,585; Berdasarkan hasil tersebut nilai tolerance semua variabel $>0,1$ dan nilai VIF semua variabel $<10$. Sehingga dapat disimpulkan tidak terjadi multikolinieritas antara variabel independen.

c. Uji Heteroskedastisitas.

Melalui grafik scatterplot dan uji Glesjer akan dilihat probabilitas signifikansi masing-masing variabel independen, apabila lebih besar dari 0,05 maka disimpulkan tidak terjadi heteroskedastisitas dalam model regresi (Ghozali, 2011).

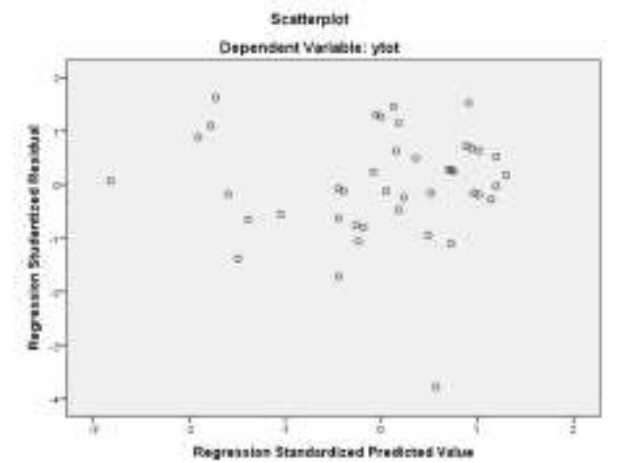

Gambar 4.1 Hasil Uji Heteroskedastisitas dengan Scatterplot 
Gambar 4.1 menunjukkan bahwa pada scatterplot titik-titik menyebar dan tidak membentuk pola tertentu yang jelas, sehingga disimpulkan tidak terjadi masalah heteroskedastisitas.

Tabel 4.13

Hasil Uji Heteroskedastisitas dengan Uji Glesjer Coefficients $^{\mathbf{a}}$

\begin{tabular}{|cc|c|c|c|c|c|}
\hline \multirow{2}{*}{} & \multicolumn{2}{|c|}{$\begin{array}{c}\text { Unstandardized } \\
\text { Coefficients }\end{array}$} & $\begin{array}{c}\text { Standardized } \\
\text { Coefficients }\end{array}$ & & \\
\cline { 2 - 5 } & Model & $\mathrm{B}$ & Std. Error & Beta & $\mathrm{t}$ & Sig. \\
\hline \multirow{2}{*}{1} & (Constant) & 4.361 & 4.136 & & 1.054 & .298 \\
& x1tot & -.078 & .111 & -.139 & -.696 & .491 \\
& x2tot & .039 & .095 & .082 & .409 & .685 \\
\hline
\end{tabular}

a. Dependent Variable: Absres

Sumber : Hasil Olah Data SPSS (2017)

Tabel 4.13 menunjukkan bahwa probabilitas signifikansi variabel kompetensi ASN sebesar 0,491 dan variabel kualitas sistem akuntansi instansi sebesar 0,685, semua variabel independen menunjukkan probabilitas signifikansi di atas tingkat kepercayaan 0,05. Dengan demikian dapat disimpulkan bahwa model regresi ini memenuhi asumsi heteroskedastisitas.

4. Analisis Regresi Berganda.

Model regresi berganda dalam penelitian ini adalah untuk menguji pengaruh kompetensi ASN (X1) dan kualitas sistem akuntansi instansi (X2) terhadap kualitas penyajian dana dekonsentrasi dalam laporan keuangan (Y). Hasil analisis regresi berganda dapa dilihat pada tabel 4.14

Tabel 4.14

Hasil Regresi Berganda

Coefficients $^{\text {a }}$

\begin{tabular}{|c|c|c|c|c|c|c|}
\hline & \multirow[b]{2}{*}{ Model } & \multicolumn{2}{|c|}{$\begin{array}{c}\text { Unstandardized } \\
\text { Coefficients }\end{array}$} & \multirow{2}{*}{$\begin{array}{l}\text { Standardized } \\
\text { Coefficients } \\
\text { Beta }\end{array}$} & \multirow[b]{2}{*}{$\mathrm{t}$} & \multirow[b]{2}{*}{ Sig. } \\
\hline & & $\mathrm{B}$ & Std. Error & & & \\
\hline & (Constant) & 18.078 & 6.122 & & 2.953 & .005 \\
\hline & x1tot & .424 & .165 & .437 & 2.573 & .014 \\
\hline & $\mathrm{x} 2$ tot & .121 & .141 & .146 & .861 & .395 \\
\hline
\end{tabular}

a. Dependent Variable: ytot

Sumber : Hasil Olah Data SPSS (2017)

Berdasarkan tabel 4.14, diperoleh persamaan regresi berganda sebagai berikut :

$Y=\alpha+\beta 1 X 1+\beta 2 X 2+e$

$Y=18,078+0,424 X 1+0,121 X 2+e$

Dengan interpretasi bahwa :

Nilai konstanta $(\alpha)$ sebesar 18,078 menunjukkan kualitas penyanjian dana dekonsentrasi dalam laporan keuangan (Y) mempunyai hubungan positif atau searah dengan kompetensi ASN (X1) dan kualitas sistem akuntansi instansi (X2).

\section{HASIL ANALISIS DAN PEMBAHASAN}

\subsection{Hasil analisis}

a. Pengaruh kompetensi ASN terhadap kualitas penyajian dana dekonsentrasi dalam laporan keuangan

1. Nilai $t_{\text {hitung }}$ dari variabel kompetensi adalah 2,573 sehingga :

$t_{\text {hitung }} 2,573>t_{\text {tabel }} 2,02269$ 
2. Signifikansi dari variabel kompetensi ASN adalah sebesar $0,014<0,05$.

3. Hal ini menunjukkan bahwa $\mathrm{Ha}_{1}$ diterima dan $\mathrm{Ho}_{1}$ ditolak, sehingga terbukti bahwa kompetensi ASN berpengaruh secara signifikan terhadap kualitas penyajian dana dekonsentrasi dalam laporan keuangan.

b. Pengaruh kualitas sistem akuntansi instansi terhadap kualitas penyajian dana dekonsentrasi dalam laporan keuangan

1. Nilai $t_{\text {hitung }}$ dari variabel kualitas sistem akuntansi instansi adalah 0,861 sehingga $\mathrm{t}_{\text {hitung }} 0,861<\mathrm{t}_{\text {tabel }} 2,02269$

2. Signifikansi dari variabel kompetensi adalah sebesar 0,395 >0,05.

3. Hal ini menunjukkan bahwa $\mathrm{Ha}_{2}$ ditolak dan $\mathrm{Ho}_{2}$ diterima, sehingga tidak terbukti bahwa kualitas sistem akuntansi instansi berpengaruh secara signifikan terhadap kualitas penyajian dana dekonsentrasi dalam laporan keuangan.

Untuk regresi dengan lebih dari dua variabel bebas digunakan adjusted $R^{2}$ sebagai koefisien determinasi. Jika nilai adjusted $R^{2}$ sama dengan 0 , maka variasi variabel independen yang digunakan dalam model tidak menjelaskan sedikitpun variasi variabel dependen. Sebaliknya adjusted $R^{2}$ sama dengan 1 , maka variasi variabel independen yang digunakan dalam model menjelaskan $100 \%$ variasi variabel dependen. Berdasarkan tabel 4.16, nilai adjusted $R^{2} 0,254$ yang artinya terhadap kualitas penyajian dana dekonsentrasi dalam laporan keuangan sebesar 25,4\% dipengaruhi oleh kompetensi ASN dan kualitas sistem akuntansi instansi, sedangkan sisanya sebesar 74,6\% dipengaruhi oleh faktor lain diluar penelitian ini.

\subsection{Pembahasan}

a. Pengaruh kompetensi ASN terhadap kualitas penyajian dana dekonsentrasi dalam laporan keuangan.

Dalam pencapaian efektivitas pengelolaan dana dekonsentrasi, pemerintah Provinsi Sulawesi Utara harus memiliki Aparatur Sipil Negara (ASN) yang mempunyai kompetensi. Penyiapan dan penyusunan laporan keuangan yang berkualitas memerlukan sumber daya manusia yang menguasai akuntansi pemerintahan (Bastian, 2006:55). Kompetensi Aparatur Sipil Negara (ASN) merupakan variabel penentu dalam meningkatkan kualitas penyajian dana dekonsentrasi dalam laporan keuangan di Provinsi Sulawesi Utara. Kompetensi yang dimiliki oleh seorang ASN meliputi pengetahuan, keterampilan, dan sikap menurut Hutapea dan Thoha dalam bukunya dengan judul Kompetensi Plus. Berdasarkan data yang diperoleh, pengelolaan ASN pengelola dana dekonsentrasi pada Pemerintah Provinsi Sulawesi Utara sudah optimal. Hal ini ditandai dengan jumlah dan kompetensi ASN pengelola dana dekonsentrasi yang sudah sesuai dengan kebutuhan.

Hal ini sejalan dengan penelitian Lia Hanif (2016) pada Pemerintah Provinsi Sulawesi Tenggara yang menyatakan bahwa kompetensi pengelola keuangan berpengaruh secara positif dan signifikan terhadap kualitas laporan keuangan daerah. Selain itu mendukung juga hasil penelitian dari Aulia Rahman (2012) yang membuktikan bahwa kompetensi mempunyai pengaruh yang signifikan terhadap kualitas pertanggungjawaban laporan keuangan dana dekonsentrasi di Satuan Kerja Pemerintah Aceh yang mengelola Dana Dekonsentrasi.

b. Pengaruh kualitas sistem akuntansi instansi terhadap kualitas penyajian dana dekonsentrasi dalam laporan keuangan.

Hasil penelitian ini tidak mendukung literatur yang berkaitan dengan manfaat dari suatu teknologi informasi dalam organisasi, termasuk pemerintah daerah yang harus mengelola dana dekonsentrasi dengan volume transaksi yang semakin meningkat dan kompleks. Penggunaan teknologi yang baik tidak selalu mendukung keberhasilan pengolahan data, hal ini disebakan oleh penggunaan sistem akuntansi instansi masih terpisah oleh dua 
aplikasi yaitu apalikasi saiba dan aplikasi sas yang masih terdapat kelemahan dalam mengekspor dan mengimport data untuk diolah menjadi laporan keuangan. Selain itu kualitas sistem akuntansi instansi yang digunakan masih terlihat tidak fleksibel atau kaku dikarenakan sistem akuntansi instansi dalam penerapannya tidak bisa mengikuti perkembangan instansi dan belum bisa mengkoreksi kesalahan yang terjadi, hal ini dikarenakan sistem akuntansi instansi dikeluarkan oleh pemerintah pusat sehingga pemerintah daerah hanya bisa menggunakannya saja. Dan kualitas sistem akuntansi instansi belum bisa digunakan di semua perangkat elektronik seperti tab maupun smartphone serta terjadi ketergantungan dalam penggunaan sistem akuntansi instansi, hal ini disebabkan tidak adanya pengkaderan ASN dalam menggunakan sistem akuntansi instansi. Dengan demikian kualitas sistem akuntansi instansi tidak dapat meningkatkan kualitas penyajian dana dekonsentrasi dalam laporan keuangan di Provinsi Sulawesi Utara dikarenakan hal-hal yang dijelaskan diatas masih terjadi dalam penerapannya di daerah.

Hasil ini sejalan dengan penelitian yang dilakukan oleh Juliani Kartika (2015) pada Satuan Kerja di Lingkungan Kementerian Pertahanan Republik Indonesia yang menyatakan bahwa implementasi sistem akuntansi instansi tidak memiliki pengaruh terhadap kualitas laporan keuangan. Selain itu mendukung juga penelitian Emilda Ihsanti (2014) yang menyatakan bahwa penerapan sistem akuntansi keuangan daerah tidak berpengaruh terhadap kualitas laporan keuangan daerah di SKPD Kabupaten Lima Puluh Kota

\section{KESIMPULAN DAN SARAN}

\subsection{Kesimpulan}

a. Dari hasil uji $\mathrm{T}$ atau secara parsial, dapat disimpulkan bahwa variabel kompetensi (X1) berpengaruh terhadap kualitas penyajian dana dekonsentrasi dalam laporan keuangan di Provinsi Sulawesi Utara

b. Dari hasil uji $\mathrm{T}$ atau secara parsial, dapat disimpulkan bahwa variabel kualitas sistem akuntansi instansi (X2) tidak berpengaruh secara signifikan terhadap kualitas penyajian dana dekonsentrasi dalam laporan keuangan di Provinsi Sulawesi Utara

\subsection{Saran}

1. Bagi peneliti selanjutnya diharapkan dapat memperluas sampel penelitian, dengan memperluas objek penelitian yang ada di Provinsi Sulawesi Utara.

2. Peneliti selanjutnya diharapkan dapat menambah variabel independen lain yang belum diteliti pada penelitian ini agar dapat mengetahui faktor-faktor lain yang mungkin mempengaruhi kualitas penyajian dana dekonsentrasi dalam laporan keuangan.

3. Peneliti selanjutnya dapat mempertimbangkan menggunakan metode-metode campuran kuantitatif dan kualitatif dalam penelitian, dimana metode kualitatif digunakan untuk menjelaskan hasil yang diperoleh dari metode kuantitatif sehingga dapat memperoleh kesimpulan yang sesuai dengan kondisi sebenarnya

\section{DAFTAR PUSTAKA}

Andini, Dewi, 2015. Pengaruh Kompetensi Sumber Daya Manusia dan Penerapan Sistem Akuntansi Keuangan Daerah terhadap Kualitas Laporan Keuangan Daerah

Abidin, Ardan, 2013. Pengaruh Penerapan Sistem Akuntansi Instansi (SAI) terhadap Kualitas Laporan Keuangan pada Komisi Pemilihan Umum Provinsi Gorontalo

AICPA. 2004. Norma Pemeriksaan Akuntan. Jakarta: Rineka Cipta.

Bachtiar Irfan, 2016. Pengaruh Aktivitas, Monitoring dan Penilaian Risiko terhadap Kualitas

Sistem Akuntansi Instansi dan dampaknya terhadap Kualitas Laporan Keuangan (Studi Kasus pada Setjen WANTANNAS RI). 
Bastian, Indra. 2010. Akuntansi Sektor Publik Suatu Pengantar Edisi Ketiga. Penerbit Erlangga :Jakarta

DeLone, William dan McLean, Ephraim. 1992. Information Systems Success: The Quest for the Dependent Variable. Information Systems Research

Ghozali, I. 2011. Aplikasi Analisis Multivariate dengan Program SPSS. Cetakan Keempat. Semarang: Badan Penerbit Universitas Diponegoro.

Hakim, Abdul. 2017. Pengaruh Kompetensi Sumber Daya Manusia, Penerapan Sistem Akuntansi Keuangan Daerah (SAKD) dan Sistem Pengendalian Intern terhadap Kualitas Laporan Keuangan PemerintahDaerah (Studi Empiris pada SKPD Kab. Ingdragiri Hulu)

Hanif, Lia. 2016. Pengaruh Kompetensi Pengelola Keuangan dan Sistem Akuntansi Keuangan Daerah terhadap Kualitas Laporan Keungan.

Hazrita Fadilah, 2014. Pengaruh Kompetensi dan Sistem Akuntansi terhadap Kualitas Pertanggungjawaban Laporan Keuangan pada Satuan Kerja di Lingkungan Kanwil Kementerian Agama Provinsi Riau.

Heidman, Marcus. 2008. The Role of Management Accounting Systems in Strategic Sensemaking. Belanda: Gabler.

Hutapea, Parulian dan Nurianna Thoha. 2008. Kompetensi Plus. PT. Gramedia Pustaka Utama: Jakarta.

Ihsanti, Emilda. 2014. Pengaruh Kompetensi Sumber Daya Manusia dan Penerapan Sistem Akuntansi Keuangan Daerah terhadap KualitasLaporan Keuangan Daerah (Studi Empiris pada SKPD Kab. Lima Puluh Kota)

Iskandar, D dan Hari Setiyawati. 2015. The Effect of Internal Accountants Competence on the Quality of Financial Reporting and the Impact on the Financial Accountability

Karika, Cahya Juliani, 2015. Pengaruh Kompetensi Sumber Daya Manusia, Implementasi Sistem Akuntansi Instansi dan Sistem Pengendalian Internal Pemerintah terhadap Kualitas Laporan Keuangan.

Keputusan Menteri Keuangan RI No.476/KMK.01/1991 tentang Sistem Akuntansi Pemerintah

Mulyadi. 2008. Sistem Akuntansi. Edisi 3. Jakarta: Salemba Empat

Nurillah, 2014. Pengaruh Kompetensi SDM, Penerapan Sistem Akuntansi Keuangan Daerah, Pemanfaatan Teknologi Informasi dan Sistem Pengendalian Intern terhadap Kualitas Laporan Keuangan Pemerintah Daerah (Studi Empiris pada SKPD Kota Depok)

Nurlis, 2017. The Influence of Internal Control Effectiveness, Information Technology Utilization and Human Resources Competence on Local Government Financial Reporting Quality (Survey on SKPD Banten Provincial Government and Serang City)

Nelson, et. al. 2005. Antecedents of Information and System Quality: An Empirical Examination Within the Context of Data Warehousing. Journal of Management Information System.

Peraturan Pemerintah Nomor 7 Tahun 2008 tentang Dekonsentrasi dan Tugas Pembantuan

Peraturan Pemerintah Nomor 8 Tahun 2006 tentang Pelaporan Keuangan dan Kinerja Instansi Pemerintah

Peraturan Pemerintah Nomor 71 Tahun 2010 tentang Standar Akuntansi Pemerintah

Peraturan Pemerintah Nomor 101 Tahun 2000 tentang Pendidikan dan Pelatihan Jabatan Pegawai Negeri Sipil

Peraturan Menteri Keuangan Nomor 213/PMK.05/2013 tentang Sistem Akuntansi dan Pelaporan Keuangan Pemerintah Pusat

Rahman Aulia, 2012. Pengaruh Kompetensi, Pelatihan dan Sistem Akuntansi Instansi terhadap Kualitas Laporan Keuangan Dana Dekonsentrasi : Studi Pada Satuan Kerja Pemerintah Aceh yang Mengelola Dana Dekonsentrasi. 
Rifa'i, Aditya, 2014. Pengaruh Etika, Kompetensi dan Pengalaman dalam Mengelola Barang Milik Negara terhadap Kualitas Laporan Keuangan Pemerintah Pusat

Rifan, Ahmad, 2015. Pengaruh Pengalaman Auditor, Supervisi dan Independensi terhadap Kinerja Audit Keuangan Negara.

Sagara, Yusar, 2015. The Effect of Implementation Accounting Information System and Competence of Human Resources on the Quality of Financial Reporting

Sapeni, Arianto, 2015. Pengaruh Sistem Akuntansi Instansi Terhadap Kualitas Laporan Keuangan Pada Pemerintah Bone Bolango

Sidik, M, 2014. Pengaruht Pertisipasi Pengguna terhadap Sistem Informasi Akuntansi dan Implikasinya pada Kualitas Informasi Akuntansi

Statement of Financial Accounting Concepts No. 8 tentang Conceptual Frameworks for Financial Reporting

Sugiyono. Metode Penelitian Pendidikan. Pendekatan Kuantitatif, Kualitatif, dan R\&D. Best Seller. Alfabeta Bandung (2014).

Sugiyono. Metode Penelitian Kuantitatif, Kualitatif, dan Kombinasi (Mixed Methods). Alfabeta Bandung (2015).

Tenaya, Agus I, 2005. Trade-off antara reliability dan relevance, e-Journal Universitas Udayana, Fakultas Ekonomi, Universitas Udayana

Undang-Undang Nomor 1 tahun 2004 tentang Perbendaharaan Negara

Undang-Undang Nomor 5 Tahun 2014 tentang Aparatur Sipil Negara

Undang-Undang Nomor 13 Tahun 2003 tentang Ketenagakerjaan

Undang-Undang Nomor 15 Tahun 2004 tentang Pemeriksaan Pegelolaan dan Tanggung Jawab Keuangan Negara

Undang-Undang Nomor 17 Tahun 2003 tentang Keuangan Negara

Undang-Undang Nomor 20 Tahun 2003 tentang Sistem Pendidikan Nasional 